\title{
DIVERSIFIKASI PENGOLAHAN IKAN SEBAGAI UPAYA PENINGKATAN EKONOMI MASYARAKAT NELAYAN DESA BAGAN SERDANG KECAMATAN PANTAI LABU KABUPATEN DELI SERDANG
}

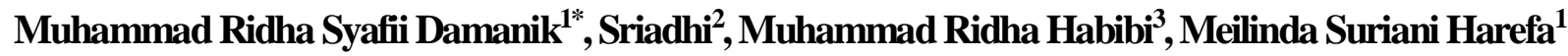 \\ ${ }^{1}$ Jurusan Pendidikan Geografi, Fakultas Ilmu Sosial, Universitas Negeri Medan, Medan, Indonesia \\ ${ }^{2}$ Jurusan Teknik Elektro, Fakultas Teknik, Universitas Negeri Medan, Indonesia \\ ${ }^{3}$ Jurusan Akuntansi, Fakultas Ekonomi, Universitas Negeri Medan, Indonesia \\ *Penulis korespondensi: mridhadamanik@unimed.ac.id
}

\begin{abstract}
Abstrak
Kegiatan Pengabdian Masyarakat ini bertujuan untuk meningkatkan perekonomian Masyarakat nelayan di Desa Bagan Serdang Kecamatan Pantai Labu Kabupaten Deli Serdang melalui diversifikasi pengolahan ikan dalam bentuk pembuatan bakso dan nugget ikan. Metode yang digunakan pada kegiatan pengabdian kepada Masyarakat ini adalah dengan cara pelatihan yang meliputi pengolahan ikan menjadi bakso dan nugget, pengemasan produk olahan ikan, pengelolaan adminitrasi dan keuangan, serta pendapingan usaha. Hasil kegiatan ini menunjukkan bahwa kelompok mitra sudah mampu dalam melakukan pengolahan ikan menjadi bakso dan nungget. Mitra juga sudah mampu mengemas dan memasarkan hasil olahan tersebut dalam lingkup lokal. Pendapatan kelompok masyarakat melalui kegiatan ini juga mulai menunjukkan hasil. Keuntungan yang dapat dihasilkan melalui pengolahan ikan dapat mencapai 80-120\%, tergantung dari jenis ikan yang digunakan.
\end{abstract}

Kata kunci: Diversifikasi Pengolahan Ikan. Ekonomi masyarakat

\begin{abstract}
Diversification of fish processing as a fishing improvement of fisherman economic effort Community service activity aims to improve the economy of fishermen community in Bagan Serdang Village, Pantai Labu District, Deli Serdang Regency, through diversification of fish processing in the form of making meatballs and fish nugget. The method used in this community service activity is by training that includes processing fish into meatballs and nuggets, packing of processed fish products, administering and finance management, and also business. The results of this activity indicate that the partner group have been able to do fish processing into meatballs and nungget. Partners also have been able to package and market the processed products within the local scope. The income of the community groups through these activities also begins to show results. Profits that can be generated through fish processing can reach 80-120\%, depending on the type of fish used.
\end{abstract}

Keywords: Diversification of fish processing. Community economy

\section{PENDAHULUAN}

Potensi ikan di Desa Bagan Serdang Kecamatan Pantai Labu Kabupaten Deli Serdang cukup besar. Hal ini didukung Desa Bagan Serdang berbatasan langsung dengan Selat Malaka. Desa ini terletak hanya \pm 1 meter di atas permukaan laut sehingga terdapat wilayahnya yang dipengaruhi oleh pasang surut. Jarak desa ini ke ibukota kecamatan hanya $4 \mathrm{~km}$, namun jaraknya ke ibukota kabupaten mencapai $20 \mathrm{~km}$. Hal ini tentunya sangat mempengaruhi perkembangan desa ini. Kondisi infrastruktur di desa ini seperti jalan, pengangkutan, air bersih, listrik, dan ketersediaan fasilitas komunikasi masih amat terbatas.Akibat akses jalan dan transportasi di dalam desa dan ke luar desa yang sangat sulit, sehinggapemasaran hasil desa dan mobilitas penduduk lebih banyak mengandalkan pengangkutan laut. Keterbatasan-keterbatasan ini menyebabkan pertumbuhan sosial ekonomi di desa ini juga menjadi sangat lambat.

Data BPS Tahun 2015 menunjukkan bahwa punduduk Desa Bagan Serdang berjumlah 1.521 jiwa yang terdiri dari 342 Kepala Keluarga. Dari jumlah tersebut, 95\% bermata pencaharian sebagai nelayan penangkap ikan di perarairan pantai. Walapun mata pencaharian dominan sebagai nelayan, namuan usaha pengolahan hasil tangkap ikan masih sangat minim. Masyarakat selama ini hanya mengandalkan penjualan ikan secara mentah sehingga nilai ekonomisnya masih sangat kecil. Berdasarkan data BPS, hanya ada $3 \mathrm{KK}$ yang bergerak dalam usaha pengolahan menjadi udang kecepe, $5 \mathrm{KK}$ pengusaha ikan asin, dan $1 \mathrm{KK}$ 
pengusaha terasi yang diolah dari udang kecepe. Namun disatu sisi, masayarakat sangat terjepit dengan masih sangat kecilnya penghasilan yang didapat oleh masayarakat yang berprofesi sebagai nelayan. Persamalahan mendasar yang menyebabkan masih minimnya masyarakat yang menegbangkan usahausaha lain untuk memperoleh pendapatan tambahan adalah karena rendahnya pengetahuan dan kreatifitas masyarakat untuk mengolah hasil tangkap mereka menjadi produk olahan dalam bentuk bakso dan nugget yang bernilai ekonomis tinggi. Pemilihan produk bakso dan nugget sebagai hasil olahan didasari dengan alasan bahawa jenis makanan ini sudah sangat populer dan disukai masyakarat. Sehingga nantinya tidak sulit untuk kelompok mitra memasarkan produk olahan ini. Berdasarkan kondisi ini, maka dinilai sangat perlu adanya pembinaan masyarakat khususnya ibu-ibu nelayan, agar dapat melakukan inovasi pengolahan ikan menjadi produk yang bernilai ekonomi tinggi sehingga dapat meningkatkan pendapatan keluarga masyarakat Desa Bagan Serdang Kecamatan Pantai Labu Tuan Kabupaten Deli Serdang.

\section{BAHAN DAN METODE}

Bahan utama yang digunakan dalam kegiatan ini terdiri dari ikan segar, tepung, bumbu, sayuran, minyak, dan bahan tambahan. Untuk pengemasan produk menggunakan bahan streofoam dan plastik wrapping. Sedangkan alat yang digunakan dalam kegiatan ini meliputi peralatan memasak seperti kompor gas, wajan, blender, chopper, dan peralatan pendukung lainnya.

Kegiatan ini merupakan bagian dari tridharma perguruan tinggi, yaiut dalam hal tanggung jawab pengabdian kepada masyarakat dalam memecahkan masalah yang berkembang. Pelaksana dalam kegiatan ini merupakan dosen dari Universitas Negeri Medan yang difasilitasi oleh Lembaga Pengabdian Kepada Masyarakat Universitas Negeri Medan. Sasaran yang menjadi mitra Unimed dalam kegiatan ini adalah kelompok ibu nelayan Desa Bagan Serdang Kecamatan Pantai Labu Kabupaten Deli Serdang Sumatera Utara (Gambar1). Kegiatan ini dilakukan pada bulan Agustus hingga September 2017.

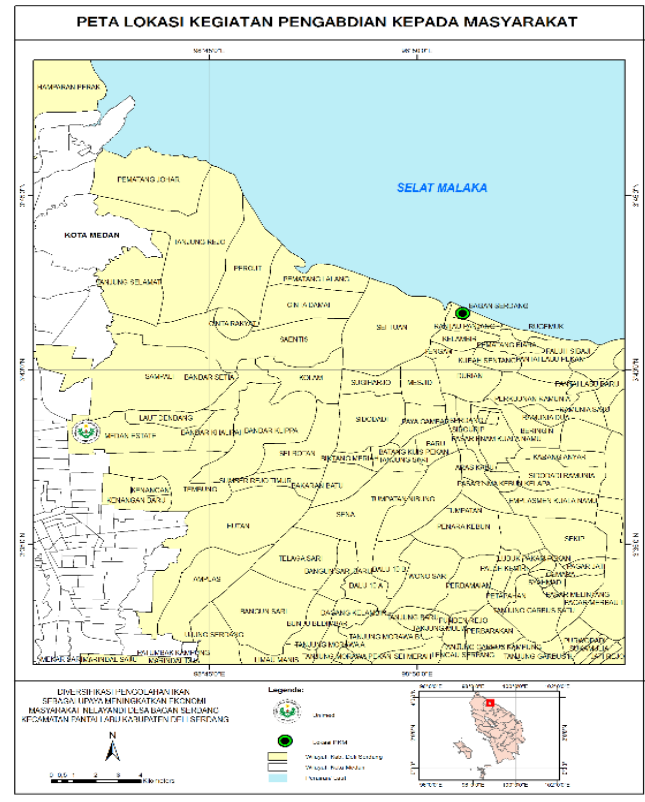

Gambar 1. Peta Lokasi Kegiatan

Metode yang digunakan dalam kegiatan ini adalah melalui pelatihan dan pendamping. Dalam pelaksanaan kegiatan pengabdian kepada masyarakat ini, tahapan pelaksanaan kegiatan meliputi:

a. Tahapan Persiapan

Tahapan persiapan ini dimulai dengan observasi lokasi kegiatan pengabdian kepada masyarakat Desa Bagan Serdang Kecamatan Pantai Labu Kabupaten Deli Serdang untuk mendiskusikan strategi pelaksanaan pengabdian kepada masyarakat di wilayah tersebut. Selanjutnya tim berkoordinasi dengan LPM-UNIMED dan instansi terkait koordinasi dan pengurusan izin pelaksanaan kegiatan serta meyepakati tanggal pelaksanaan.Pada tahap pesiapan ini, tim melakukan penyiapan sarana prasaran pelaksanaan kegiatan seperti peralatan standar minimal yang dimiliki oleh mitra sasaran dalam pengembangan usaha.

b. Tahap Pelatihan Produksi.

Pelatihan produksi ini diberikan kepada kelompok mitra dimulai dari pemilihan bahan baku olahan dan pelatihan cara pengolahan berupa ikan segar. Kegiatan ini bersifat aktif dengan melibatkan peran mitra dalam proses pengolahan produksi. Materi dalam pelatihan ini diberikan kepada setiap peserta pelatihan untuk mempermudah peserta mencoba mengulang kembali secara mandiri sesuai dengan panduan materi yang diberikan. Sehingga kesiapan kelompok mitra menjadi pengusa nugget ikan dan bakso ikan dapat terealisasi sebagai upaya peningkatan perekonomian keluarga.

c. Pelatihan Mendesain Kemasan dan Pemasaran Pada pelatihan ini, kelompok mitra diberikan pelatihan mendesain kemasan produk olahan bernilai jual sehingga kemasan memeiliki daya tarik untuk dijual disamping kemasan dapat difungsikan untuk pengawetan makanan. Setelah 
pelatihan pengemasan, kelompok mitra diberikan keterampilan memasarkan produk hasil olahan kepada konsumen agar usaha yang dikembangkan ini dapat berkelanjutan.

d. Pendampingan

Setelah pelatihan dilaksanakan, kelompok mitra didampingi sampai pada tingkat terampil. Target dari pendampingan yang dilakukan kepada kelompok mitra adalah:

- $\quad$ Mitra telah terampil mengolah produk nugget ikan dan bakso ikan dan berinovasi dengan produk olahan sehingga mampu memodifikasi olahan dengan rasa yang khas.

- Mitra telah memiliki desain kemasan yang khas dan menjadi ciri produksi olahan mitra.

- $\quad$ Mitra telah memiliki pasar yang menampung hasil olahan mitra

- Mitra telah memiliki administrasi dan pembukuan yang diterapkan pada pengelolaan usaha nugget ikan dan bakso ikan.

Keberhasilan kegiatan ini tidak lepas dari peran serta dan partisipasi mitra. Oleh sebab itu, dalam rencana kegiatan, partisipasi mitra ditetapkan secara jelas dan menjadi tanggung jawab mitra untuk mencapai luaran masing-masing tahapan dan tujuan akhir kegiatan. Adapun uraian pelaksanaan kegiatan, luaran, dan bentuk partisipasi mitra dapat dilihat pada tabel 1 .

Tabel 1. Uraian Rencana Kegiatan, Luara, dan Partisipasi Masyarakat

\begin{tabular}{|c|c|c|c|c|}
\hline $\begin{array}{l}\mathbf{N} \\
\mathbf{0}\end{array}$ & $\begin{array}{l}\text { Rencana } \\
\text { Kegiatan }\end{array}$ & $\begin{array}{l}\text { Metode } \\
\text { Pendekatan }\end{array}$ & Target/Luaran & $\begin{array}{l}\text { Partisipasi } \\
\text { Mitra }\end{array}$ \\
\hline 1 & $\begin{array}{l}\text { Observasi } \\
\text { kegiatan }\end{array}$ & $\begin{array}{l}\text { Identifikasi } \\
\text { kebutuhan } \\
\text { kelompok } \\
\text { mitra dalam } \\
\text { pengambanga } \\
\text { n usaha }\end{array}$ & $\begin{array}{l}\text { Data potensi } \\
\text { pengembangan } \\
\text { usaha mitra }\end{array}$ & $\begin{array}{l}\text { Aktif dalam } \\
\text { penyampaia } \\
\text { n data } \\
\text { keberadaan } \\
\text { dan potensi } \\
\text { mitra }\end{array}$ \\
\hline 2 & $\begin{array}{l}\text { Pengadaan } \\
\text { dan } \\
\text { penggunaa } \\
\text { n peralatan } \\
\text { olahan } \\
\text { nugget } \\
\text { ikan dan } \\
\text { bakso ikan }\end{array}$ & $\begin{array}{l}\text { Menyiapkan } \\
\text { peralatan } \\
\text { pelaksanaan } \\
\text { usaha sesuai } \\
\text { dengan } \\
\text { standar } \\
\text { minimum } \\
\text { pengembanga } \\
\text { n usaha dan } \\
\text { uji coba } \\
\text { penggunaan } \\
\text { alat oleh } \\
\text { mitra } \\
\end{array}$ & $\begin{array}{l}\text { Alat pengolahan } \\
\text { standar } \\
\text { minimum } \\
\text { dimiliki mitra } \\
\text { dan mitra } \\
\text { terlatih } \\
\text { menggunakanny } \\
\text { a }\end{array}$ & $\begin{array}{l}\text { Mitra aktif } \\
\text { berlatih } \\
\text { menggunaka } \\
\mathrm{n} \text { peralatan } \\
\text { untuk } \\
\text { pengolahan } \\
\text { nugget ikan } \\
\text { dan bakso } \\
\text { ikan sebagi } \\
\text { produk } \\
\text { unggulan } \\
\text { mitra }\end{array}$ \\
\hline 3 & $\begin{array}{l}\text { Pelatihan } \\
\text { produksi } \\
\text { nugget } \\
\text { ikan dan } \\
\text { bakso ikan }\end{array}$ & $\begin{array}{l}\text { Praktek dan } \\
\text { simulasi }\end{array}$ & $\begin{array}{l}\text { Mahir mengolah } \\
\text { nugget ikan dan } \\
\text { bakso ikan yang } \\
\text { memiliki ciri } \\
\text { khas produk } \\
\text { unggulan mitra }\end{array}$ & $\begin{array}{l}\text { Berpartisipas } \\
\text { i aktif dalam } \\
\text { pelatihan } \\
\text { pengolahan } \\
\text { produk }\end{array}$ \\
\hline 4 & $\begin{array}{l}\text { Pelatihan } \\
\text { pengemasa } \\
\text { n dan } \\
\text { pemasaran }\end{array}$ & $\begin{array}{l}\text { Praktek } \\
\text { desain } \\
\text { kemasan }\end{array}$ & Desain kemasan & $\begin{array}{l}\text { Aktif } \\
\text { memilih } \\
\text { desain } \\
\text { kemasan dan } \\
\text { mencari } \\
\text { pasar untuk } \\
\text { penampunga } \\
\text { n produk } \\
\text { olahan }\end{array}$ \\
\hline
\end{tabular}

\begin{tabular}{|c|c|c|c|c|}
\hline & & & & $\begin{array}{l}\text { nugget ikan } \\
\text { dan bakso } \\
\text { ikan yang } \\
\text { dihasilkan } \\
\text { oleh mitra }\end{array}$ \\
\hline 5 & $\begin{array}{l}\text { Pelatihan } \\
\text { administras } \\
\text { i dan } \\
\text { keuangan }\end{array}$ & $\begin{array}{l}\text { Praktek } \\
\text { penggunaan } \\
\text { aplikasi } \\
\text { administrasi } \\
\text { dan keuangan } \\
\text { pada usaha } \\
\text { mitra }\end{array}$ & $\begin{array}{l}\text { Laporan } \\
\text { keuangan } \\
\text { manual dan } \\
\text { sistem IT }\end{array}$ & $\begin{array}{l}\text { Berperan } \\
\text { aktif dalam } \\
\text { pelatihan } \\
\text { dan } \\
\text { memahami } \\
\text { admintrasi } \\
\text { dan } \\
\text { keuangan } \\
\text { yang } \\
\text { digunakan } \\
\text { pada usaha } \\
\text { mitra }\end{array}$ \\
\hline
\end{tabular}

Bentuk keterapilan yang akan dilatihkankan kepada masyarakat melalui diversifikasi hasil olahan ikan adalah dalam dalam produk bakso dan nugget. Adapun alur pembuatan nugget dan bakso berbahan dasar ikan dapat dilihat pada Gambar 2.

ALUR PROSES PEMBUATAN NUGGET IKAN

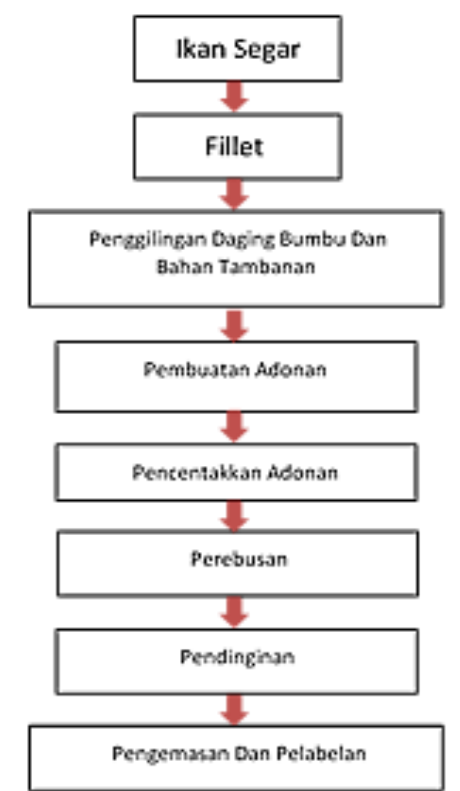

ALUR PROSES PEMBUATAN BAKSO IKAN

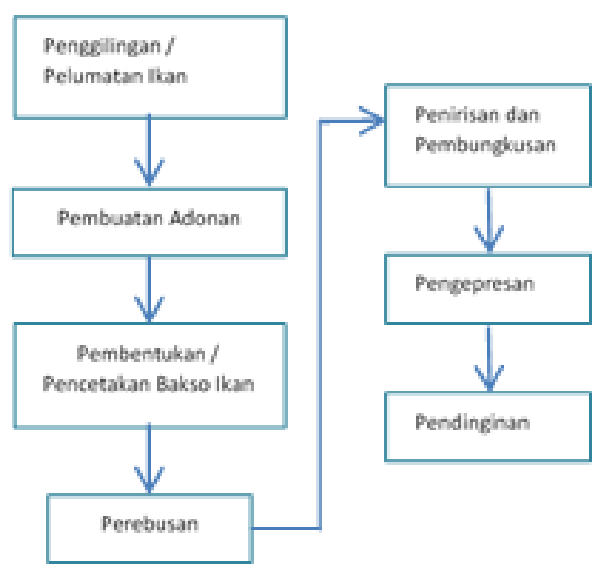

Gambar 2. Alur kegiatan pembuatan nugget ikan dan bakso 


\section{HASIL DAN PEMBAHASAN}

Salah satu hasil yang diperoleh oleh kelompok mitra dalam kegiatan ini adalah aset usaha dalam bentuk peralatan pengolahan yang terdiri dari alat masak, alat penghalus bumbu, dan alat pengemas. Dengan adanya capaian ini, maka permasalahan belum adanya modal peralatan usaha sudah dapat diatasi olehkelompok mitra. Seluruh peralatan ini sudah dipergunakan oleh mitra untuk mengmbangkan usaha pembuatan bakso dan nugget ikan.

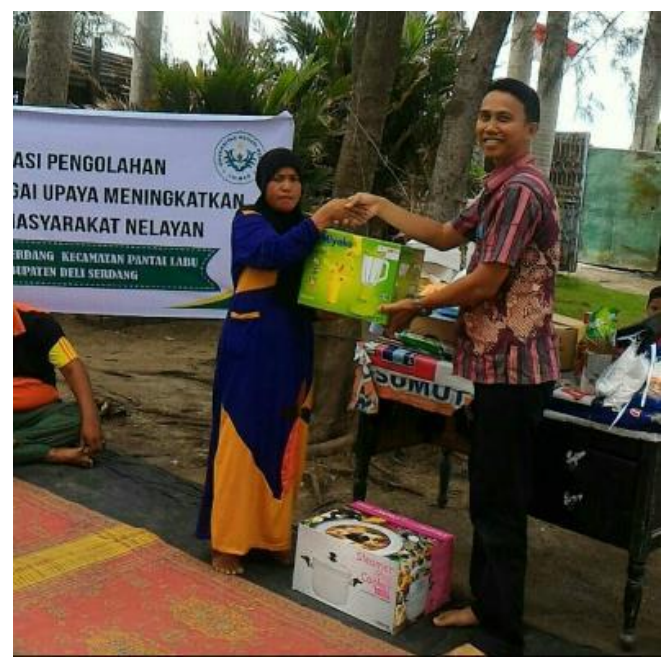

Gambar 3. Penyerahan peralatan pengolahan ikan sebagai aset kelompok mitra.

Pelasanaan pelatihan pengolahan ikan menjadi bakso dan nugget di Desa Bagan Serdang sudah berhasil dilaksanakan dengan baik sesuai dengan rencana kegiatan. Kelompok masyarakat mitra sangat antusias mengikuti dan menerima pendapingan yang dilakukan oleh tim kegiatan pengabdian. Mitra juga sudah mampu mengolah ikan jenis kakap, pari, dan terubuk menjadi bakso dan nungget. Dalam kegiatan tersebut, 17 orang ibu-ibu nelayan telah terampil dalam pengolahan bakso dan nugget berbahan dasar ikan.

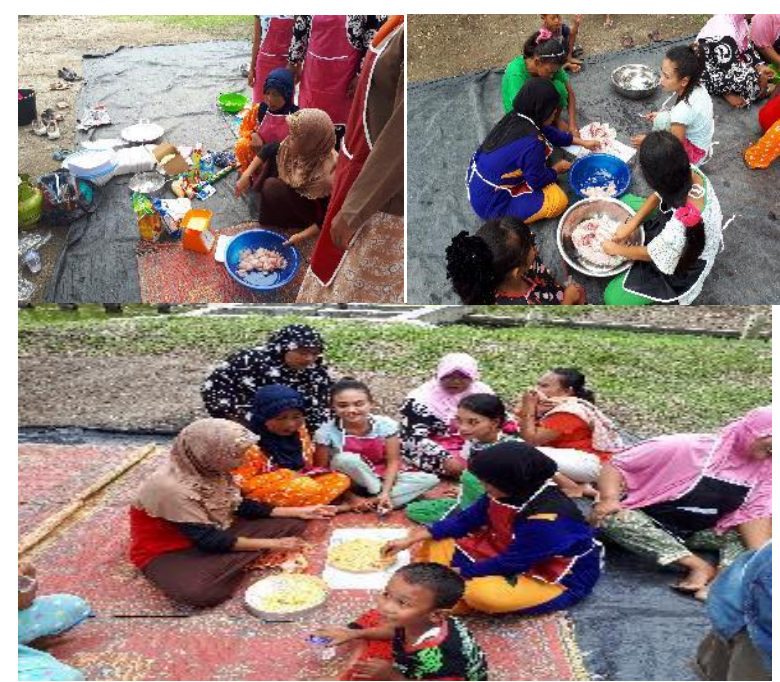

Gambar 4. Pelaksanaan Pelatihan Pengolahan Ikan menjadi Baksi dan Nungget (Sumber: Pelaksanaan Kegiatan, 2017)
Pada tahapan pelasanaan pelatihan pembuatan bakso dan nugget berbahan dasar ikan, kelompok masyarakat sudah mampu menghasilkan $1 \mathrm{~kg}$ bakso dan $1 \mathrm{~kg}$ nugget. Bakso dan nungget yang dihasilkan berbahan dasar ikan kakap. Jenis ikan ini memang memiliki harga modal yang tinggi. Namun sebagai tahap awal pembuatan, perlu digunakan bahan dasar yang memiiki kulitas tinggi untuk menghasilkan rasa yang lebih enak. Dalam penilaian hasil produk, rasa bakso dan nungget yang diproduksi sangat memuaskan.

Proses kerja pengolahan bakso dan nungget oleh kelompok mitra dinilai sudah baik. Kemampuan kelompok mitra untuk mengikuti dan melaksanakan setiap langkah dan tahapan kerja sudah sesuai dengan prosedur yang ditetapkan. Aspek kebersihan dan ketertiban kerjakelompok mitra juga dinilai sangat baik.
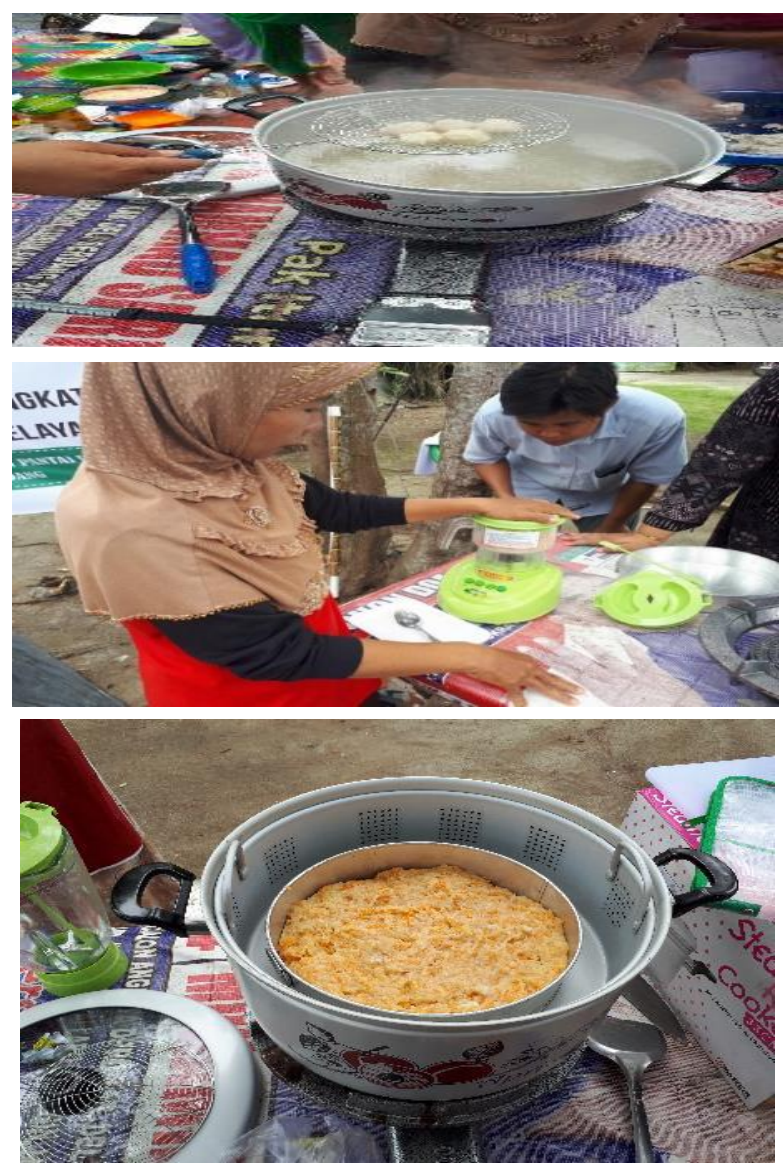

Gambar 5. Proses kerja kelompok mitra dalam pengolahan ikan menjadi bakso dan nungget (Sumber: Pelaksanaan Kegiatan, 2017)

Untuk meningkatkan nilai produk, maka bakso dan nungget dikemas dalam keamasan yang lebih higienis dan menanrik. Kelompok mitra juga didampingi untuk mampu melakukan pengemasan produk. Dalam pelaksanaanya, produk olahan bakso dan nungget dikemas menggunakan sterefoam dan plastik wrapping untuk menjaga keawetan dan kebersihan produk. Hasilnya, kelompok mitra dapat mengikuti pelatihan pengemasan dengan baik dan mampu 
mengemas produk dengan sangat rapi (Gambar 5). Pengemasan yang dihasilkan dinilai sudah sangat baik dan sesuai dengan standar layak untuk masuk ke pasar modern.

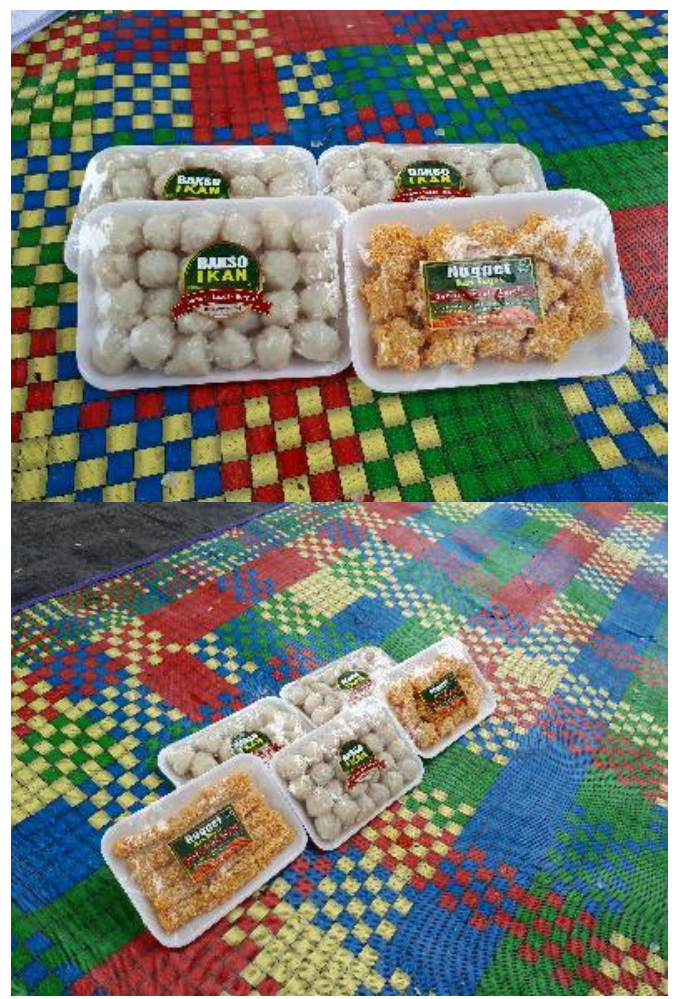

Gambar 5. Produk hasil olahan bakso dan nugger yang telah dikemas (Sumber: Pelaksanaan Kegiatan, 2017).

Pelakasanaan kegiatan ini juga menekankan pada aspek inovasi dan keberlanjutan. Ditinjau dari aspek inovasinya, kelompok mitra juga mencoba untuk mengembangkan pengolahan ini pada jenis ikan yang lain yang memiliki harga yang relatif lebih murah. Hasilnya kelompok mitra berhasil mengolah bakso dan nungget ikan dari bahan ikan pari dan ikan terubuk. Pemilihan jenis ini didasari karena jenis ikan ini umumnya kurang diminati oleh masyarakat jika dimakan langsung dan harga jualnya mentahnya relatif murah, sehingga dengan adanya pengolahan menjadi bakso dan nugget, jenis ikan tersebut dapat lebih bernilai ekonomis. Kelompok mitra juga sudah mencoba memasarkan produk tersebut walapun masih dalam tingkat lokal. Hasilnya masyarakat dapat menjual produk seharga Rp 10.000 per paket. Dengan harga tersebut, kelompok mitra dapat menghasilkan keuntungan 80-120\% dari modal bahan baku. Kendala yang dijumpai adalah belum adanya standarisasi BPOM terkait produk yang dihasilkan sehinga tentunya kepercayaan publik masih belum tinggi terhadap produk hasil. Selain berinnovasi dalam hal jenis ikan, kelompok mitra juga melakukan inovasi dengan mengolah produk hasil menjadi bahan siap makan dalam bentuk bakso bakar, bakso goreng, dan nugget goreng. Hasil olahan ini juga dinilai cukup efektif untuk meningkatkan nilai produk, sehingga tentunya dapat terus dikembangkan.
Dari aspek keberlanjutan, kelompok mitra juga terus melakukan produksi terhadap bakso dan nugget ikan. Kelompok juga berkomitmen untuk secara bersamasama mengembangkan usaha ini sehingga bisa menjadi salah satu produk unggulan desa yang dapat diandalkan untuk meningatkan kesejahteraan masyarakat desa.

\section{KESIMPULAN}

Berdasarkan hasil yang diperoleh dapat disimpulkan bahwa diversifikasi pengolahan ikan merupakan salah satu cara yang sangat efektif untuk meningkatkan pendapatan masyarakat di daerah pesisir. Cara ini sangat efektif sebab hasil tangkap nelayan sangat rentan mengalami kerusakan. Adanya diversifikasi tersebut, maka kerusakan ikan akibat waktu dapat dihindari dan nilai jual hasil akan semakin meningkat. Sasaran kelompok masyarakat yang paling efektif untuk usaha diversifikasi olahan ikan adalah ibu-ibu nelayan sebab umumnya ibu-ibu nelayan memiliki waktu luang yang lebih banyak. Keuntungan yang dapat diperoleh dari hasil olahan ikan dalam bentuk bakso dan nungget dapat mencapai $80-120 \%$ dari modal bahan dasar.

Adapaun rencana lanjutan yang dapat dilakukan dari kegiatan ini adalah menguji kandungan gizi dari produk yang dihasilkan dan mengurus izin dari BPOM serta memperluas wilayah pesamarannya.

\section{UCAPAN TERIMA KASIH}

Ucapan terima kasih disampaikan kepada Universitas Negeri Medan khususnya Lembaga Pengabdian Kepada Masyarakat (LPM) Unimed yang telah memberikan alokasi dana untuk pelaksanaan kegitan ini. Selain itu, ucapan terima kasih juga disamapaikan kepada kelompok mitra ibu-ibu nelayan dan jajaran perangkat Desa Bagan Serdang yang sangat membantu salam terlaksanakanya kegiatan ini. Ucapan terima kasih juga disampaikan kepada selutuh tim pengabdian kepada masyarakat yang sudah berkontribusi pikiran dan waktu untuk mensukseskan kegiatan ini.

\section{DAFTAR PUSTAKA}

BPS Kabupaten Deli Serdang, 2015. Kecamatan Pantai Labu dalam Angka Tahun 2015.

Taampubolon, Dewi Murni. Ahmad. Nurmatias. 2011. Analisis Finansial Usaha Perikanan Yang Berbeda Pemasarannya. Jurnal Perikanan dan Kelautan Vol 16. 1.

fpik.bunghatta.ac.id/request.php?527diakses tanggal 4 Juli 2017

https://www.google.co.id/url?sa=t\&rct=j\&q=\&esrc=s $\&$ source $=$ web $\& c d=4 \&$ cad $=$ rja\&uact $=8 \&$ ved $=0$ ahUKEwj15sTX1KDWAhUJtI8KHQDKBdYQ Fgg9MAM\&url=http\%3A\%2F\%2Fdirectory.u mm.ac.id\%2Fpenelitian\%2FPKMI\%2Fpdf\%2F PEMBUATAN\%2520NUGGET\%2520IKAN. pdf\&usg=AFQjCNH_Cid6WEzOMMjPrj4PvYZzfHgEw. Diakses 4 juli 2017 